Talking Peace at the Edge of War: Local Civil Society Narratives and Reconciliation in Eastern Ukraine

Author(s): Ganna Bazilo, Giselle Bosse

Source: Kyiv-Mohyla Law and Politics Journal 3 (2017): 91-116

Published by: National University of Kyiv-Mohyla Academy

http://kmlpj.ukma.edu.ua/ 


\title{
Talking Peace at the Edge of War: Local Civil Society Narratives and Reconciliation in Eastern Ukraine
}

\author{
Ganna Bazilo, \\ Independent researcher
}

Giselle Bosse,

Maastricht University

\begin{abstract}
Scholarly works on Ukraine conflict and its resolution tend to focus on the role of states or international organizations. Yet, more and more local civil society organizations (CSOs) are embracing reconciliation as a new agenda in the post-Euromaidan period. In this article, we analyze the role of local Ukrainian CSOs in fostering dialogue and reconciliation in Eastern Ukraine. Research on sub-state actors as legitimate agency in peacebuilding in Eastern Ukraine remains scarce. By drawing on the "everyday peace" perspective, we show that local bottom-up narratives of the conflict differ greatly from the top-down narratives of states and international organizations. Whereas the latter tend to reconfirm the status quo of the conflict or the (neo-) liberal economic approach to peace, local CSOs promote "rehumanizing the other," which constitutes a quintessential process in achieving sustainable peace in Eastern Ukraine.
\end{abstract}

Key Words: Ukraine, conflict, reconciliation and dialogue, civil society, peace narratives.

\section{(2)}

\section{Introduction}

Since 2014, over 3.8 million people have been affected by the conflict in Ukraine. ${ }^{1}$ It is estimated that more than 1.7 million people from Donbas region and the Autonomous Republic of Crimea have been internally displaced. ${ }^{2}$ As result of the annexation of Crimea by the Russian Federation and ongoing military conflict in Eastern Ukraine, and especially of the widespread internal displacement, tensions have developed between Internally Displaced Persons (IDPs) and some host communities. There have been reports about tensions between returning IDPs and non-displaced population due to their different experiences during the conflict, as well as

1 Humanitarian Bulletin Ukraine 15 (October-December 2016), accessed March 16, 2017, http:// reliefweb.int/report/ukraine/humanitarian-bulletin-ukraine-issue-15-1-october-31-december-2016. "Humanitarian Needs Overview 2016," November 2015, accessed March 16, 2017, http://www. globalprotectioncluster.org/_assets/files. 
of human rights violations on both sides of the conflict. ${ }^{3}$ Moreover, social cohesion and trust have dramatically deteriorated in communities separated by the frontline between Ukrainian government-controlled and non-government-controlled territories in the Donetsk and Luhansk regions.

In an effort to create a more stable environment and promote peace and reconciliation in Ukraine, the Ukrainian government and the wider international community have initiated various peacebuilding and reconciliation activities. ${ }^{4}$ Millions of dollars in bilateral and multilateral assistance have already been pledged or donated to peacebuilding and other development programs in Ukraine.

The "high politics" of the crisis in Ukraine and strategic involvement of the Russian Federation, the United States (US) or the European Union (EU) have so far dominated the academic discourse on the Ukrainian conflict and its resolution. Some scholarly works also address the peacebuilding efforts by the Ukrainian government and the international community. ${ }^{5}$ Whilst undeniably recognizing that governments and international organizations are primary actors in peacebuilding efforts in Ukraine, this article proposes to shift attention to bottom-up activities of civil society organizations (CSOs) in support of dialogue and reconciliation in the country.

Local civil society efforts to support peace matter for two reasons. First, while the high-level negotiations and implementation of the Minsk II peace agreement are stuck on crucial elements, local reconciliation efforts can help defuse tensions in high-risk areas, prepare the ground for a future political settlement, address the needs and concerns of local communities affected by the conflict and promote reconciliation between groups and communities that have been driven apart by the conflict. Second, like in many peace processes, decisions in the Minsk process have been taken behind closed doors. Although the need for confidentiality in a peace process is understandable, the failure to inform and involve the wider population and communities directly affected may impact negatively on the long-term sustainability of the peace process. Ukrainian CSOs therefore play a vital role in bringing important discourses on peace into the public domain and thereby involving the population in the peace process.

Despite recognizing the importance of local CSOs in promoting peace in Ukraine, ${ }^{6}$ efforts to reach a peaceful conflict resolution and peace activism by civil society are still met with skepticism by the Ukrainian government and parts of the wider population. Consequently, the

3 Office of the United Nations High Commissioner for Human Rights, HRMMU, "Report on the Human Rights Situation in Ukraine—16 February to 15 May 2016," accessed March 16, 2017, http://www.ohchr. org/Documents/Countries/UA/Ukraine_14th_HRMMU_Report.pdf.

4 UNHCR Protection Cluster Ukraine, “Peacebuilding and Reconciliation in Ukraine," July 2016, accessed January 15, 2017, http://unhcr.org.ua/attachments/article/317/ Peacebuilding\%2oAnd\%2O Reconciliation_Guidance\%2oNote_Final-ENG.pdf.

5 For example, Sylvia Rognvik, “Dialogue Facilitation,” Norwegian Centre for Human Rights, May 2016, accessed March 4, 2017, http://www.jus.uio.no/smr/english/about/programmes/nordem/ publications/nordemthematicpaper_oscesmm_dialogue-facilitation.pdf.

6 OSCE, "Civil Society and the Crisis in Ukraine," Thematic Report, February 11, 2015, accessed on April 25, 2017, http://www.osce.org/ukraine-smm/141046?download=true. 
interest in CSOs peace activities has been limited, and research into the goals, motivations and diverse roles of CSOs in fostering reconciliation in Ukraine remains scarce.

In light of the above, the aim of our article is to analyze the role of civil society in fostering dialogue and reconciliation in Eastern Ukraine.

As the conflict in Eastern Ukraine has confronted Ukraine and its people with an unprecedented challenge, the country's political and societal elites, including local CSOs, have little experience in mediation and dialogue facilitation. ${ }^{7}$ Therefore, we contribute a case study to this special issue that focuses on peacebuilding as a "new agenda" of civil society in Ukraine.

The conflict in Ukraine affects also the territory of illegally annexed Crimea, resulting in more than 20 ooo IDPs who fled the peninsula due to the annexation. However, our research is primarily concerned with the analysis of the role of CSOs active in fostering dialogue and reconciliation in Eastern Ukraine. We also focus on regions, which are hosting IDPs, the majority of which are from Donbas. It was observed that a number of CSOs have emerged as a result of the Euromaidan protests or have reoriented the activities of already existing non-governmental organizations (NGO) and networks in order to respond to the evolving need for building dialogues in society as the conflict shifted to Crimea and Eastern Ukraine.

It is not our ambition to present a representative survey of CSOs engaged in reconciliation in Ukraine, and neither do we seek to provide a fully-fledged impact assessment of their activities. Rather, our aim is to introduce the CSOs that we found to be actively engaged in dialogue and reconciliation activities and to better understand their narratives of the origins of the conflict, their definitions of peace and reconciliation, and their views on the purpose and role of their organizations in reconciliation processes.

We draw on Mac Ginty's concept of the "everyday peace," which defines local actors as an important agency in peacebuilding processes. ${ }^{8}$ Local CSOs are likely to advance what Carolyn Nordstrom has termed "a different kind of war story," which may not only differ considerably from how top-down actors (governments, international community) frame conflict but also challenge dominant narratives of conflict, division and suspicion. CSO narratives may "constitute a category of resistance, especially to the division and incompatibility that may be preferred by political and military elites." 9 Due to the ongoing conflict, the "militarization of public discourse around the conflict is still pervasive" in Ukraine. ${ }^{10}$ Thus, the role of local reconciliation narratives cannot be underestimated. In addition, the bottom-up narratives of Ukrainian CSOs may challenge increasingly technocratic approaches to peacebuilding employed by international NGOs and international organizations. Much reconciliation activity has been standardized through "best

Tatiana Kyselova, “Mediation Development in Ukraine: 1991-2015," Working Paper, January 6, 2016, accessed on May 8, 2017, https://www.academia.edu/20286554/Mediation_Development_in_ Ukraine_1991-2016.

8 Roger Mac Ginty, "Everyday Peace: Bottom-up and Local Agency in Conflict-Affected Societies," Security Dialogue 45.6 (2014): 548-64.

9 Mac Ginty, “Everyday Peace," 555.

10 Giulia Pasquienelly, "Peacebuilding in Ukraine: A Long Way to Go," May 7, 2016, Agency for Peacebuilding, accessed December 15, 2016, http://www.peaceagency.org/en/2016/o5/o7/ peacebuilding-in-ukraine-a-long-way-to-go. 
practices" or "lessons learned." As Mac Ginty and others have argued, such activities have "often had positive outcomes" but they "reinforce the notions that 'expertise' is exogenous and that local actors ... are passive victims and recipients who lack the agency to chart their own path unaided." 11

Our article is structured as follows: first, we introduce the concept of the "everyday peace," develop a typology for analyzing different narratives of conflict and reconciliation, and outline the data collection methodology. We then examine the narratives of seven local Ukrainian CSOs. By way of conclusion, we compare the bottom-up narratives of the CSOs with the main understandings of the conflict, peace and reconciliation articulated by the Ukrainian government and the international community.

\section{Defining and Researching the Role of CSOs in "Everyday Peace"}

When explaining the origins of the Ukraine conflict or discussing opportunities for its resolution, the vast majority of scholarly works focus on the roles and interests of the Russian Federation, the US, the North Atlantic Treaty Organization (NATO) or the EU and its Member States. On one side of the debate are those arguing that geopolitics and power politics are back or had never left. The Ukraine crisis is essentially the "West's fault" for it had meddled with countries in Russia's perceived sphere of influence and therefore provoked a harsh counter-reaction. ${ }^{12}$ Others regard Russia as the main cause of the conflict, acting as a "revanchist, revisionist and disruptive" power ${ }^{13}$ or at least a "part-time spoiler." 14 Yet others underline that the EU's leadership is to blame for its "appeasement towards dictators." 15 Some authors also argue that both the Russian and the EU's leadership are to blame, ${ }^{16}$ underlining the "unfinished process of mutual readjustment of two identities-in-the-making, that of post-Soviet Russia and post-Lisbon EU"17 and the necessity to

11 Mac Ginty, “Everyday Peace,” 551. See also: Laurent Goetschel and Tobias Hagmann, “Civilian Peacebuilding: Peace by Bureaucratic Means? Analysis," Conflict, Security \& Development 9.1 (2009):

$55^{-73}$.

12 John J. Mearsheimer, "Why the Ukraine Crisis is the West's Fault: The Liberal Delusions that Provoked Putin," Foreign Affairs 93.5 (2014): 77.

13 Anne Applebaum, "War in Europe Is Not a Hysterical Idea," Washington Post, August 29, 2014, accessed December 17, 2016, http://www.washingtonpost.com/opinions/anne-applebaum-war-ineurope-is-not-a-hysterical-idea/2014/o8/29/815f29d4-2f93-11e4-bb9b-997aeg6fad33_story.html.

14 John G. Ikenberry, "The Illusion of Geopolitics: The Enduring Power of the Liberal Order," Foreign Affairs 93 (2014): 80.

15 Geoffrey Pridham, "EU/Ukraine Relations and the Crisis with Russia, 2013-14: A Turning Point," The International Spectator 49.4 (2014): 53-61.

16 Anke Schmidt-Felzmann, "The Breakdown of the EU's Strategic Partnership with Russia: From Strategic Patience Towards a Strategic Failure," Cambridge Review of International Affairs 29.1 (2016): 99-127.

17 Aliaksei Kazharski and Andrey Makarychev, "Suturing the Neighborhood? Russia and the EU in Conflictual Intersubjectivity," Problems of Post-Communism 62.6 (2015): 328-39. 
"reconcile different worldviews." ${ }^{18}$ Common to all of these accounts is a state-centric perspective, which places an exclusive focus on states as the sole and most relevant actors in the Ukraine conflict and its resolution. Few scholarly works look beyond or within states to analyze the conflict. Adopting a domestic politics approach, Dragneva and Wolczuk examine Ukraine's integration behavior, ${ }^{19}$ while Strasheim evaluates the behavior of the Ukrainian leadership more specifically. ${ }^{20}$ Yet, also here an emphasis is placed on the actions of political or economic elites, such as government officials, political parties or oligarchs. As a result of the over-emphasis on states and political elites, research on the role of civil society as a relevant and legitimate actor in the Ukrainian conflict, specifically in processes of conflict resolution, is scarce.

The scholarly debates on the Ukraine conflict broadly mirror the dominant trend in the study of peace and conflict, which has also long been dominated by orthodox and statist research agendas, which often concentrate on "institutions and traditional views of security and peace." ${ }^{21}$ Although the "local turn" in peace and conflict studies was first introduced over two decades ago, ${ }^{22}$ the focus on local actors and civil society, localized rights or local identities has remained highly contested and is often "rebuffed as romantic, relativist or particularistic, anti-democratic" or "anti-developmental." ${ }^{23}$ In recent years, however, the critical research agenda that seeks to recognize the agency and significance of actors at the sub-state level has re-gained considerable momentum with the introduction of the notion of "everyday peace." 24

The concept of everyday peace recognizes the important role of local CSOs in peacebuilding processes. Researching everyday peace practices involves moving away from statist research agendas and traditional (static) views on conflict, security and reconciliation. Drawing on the notion of human security, everyday peace is "context specific and involves observations and decisions made by individuals and communities." ${ }^{25}$ Thus, everyday peace rests on considerable agency at the individual and group levels. It is often exercised in the face of overwhelming power held by states. Everyday peace practices do more than "eking out space for 'normal' existence in the midst of conflict" 26 by challenging the norm that conflict and division are the only modes of

18 Pernille Rieker and Kristian Lundby Gjerde, "The EU, Russia and the Potential for DialogueDifferent Readings of the Crisis in Ukraine," European Security 25.3 (2016): 304-25.

19 Rilka Dragneva-Lewers and Kataryna Wolczuk, Ukraine Between the EU and Russia: The Integration Challenge (Houndmills; Basingstoke; New York: Palgrave Macmillan, 2015). Julia Strasheim, “Domestic Explanations for War and Peace in Ukraine," GIGA Working Paper 287 (2016).

21 Roger Mac Ginty and Pamina Firchow, "Top-down and Bottom-up Narratives of Peace and Conflict," Politics 36.3 (2016): 309 .

John Paul Lederach, Preparing for Peace: Conflict Transformation across Cultures (Syracuse, NY: Syracuse University Press, 1995). Roger Mac Ginty and Oliver P. Richmond, "The Local Turn in Peace Building: A Critical Agenda for Peace," Third World Quarterly 34.5 (2013): 764.

24 Mac Ginty, "Everyday Peace.”

25 Mac Ginty and Firchow, "Top-down and Bottom-up Narratives," 309.

26 Mac Ginty, "Everyday Peace," 56o. 
intergroup relations or bypassing approved methods of communication to establish new modes of contact.

In our study, we therefore focus on the narratives of local Ukrainian CSOs, which operate by and large independent of national and international peacebuilding efforts and donor programs. The identification and localization of independent reconciliation CSOs proved cumbersome, because many groups are wary of publicity as it could jeopardize their work, or they remain inherently suspicious of "strangers" enquiring about their activities. A handful of studies on this topic provide an overview of the existing civil society organizations and initiatives. The most exhaustive information was obtained from an online Dialogue Support Platform developed by the MediatEUr, ${ }^{27}$ a publication by the International Center for Policy Studies (ICPS) named "Mapping of Dialogue Initiatives to Resolve Conflict in Eastern Ukraine," 28 OSCE Thematic Report on "Civil Society and the Crisis in Ukraine" 29 and a working paper on "Mediation Development in Ukraine: 1991-2015."30

Hence, a total population of twenty-five independent CSOs which are involved in dialogue facilitation for peacebuilding and reconciliation was identified, seven of which were willing to participate in our research. Interviews with the CSOs took place between November 2016 and January 2017. For information on origins, geography of the CSOs, please refer to the table in Annex I. Any numbering has been omitted from the table to ensure CSOs enjoy a sufficient level of anonymity to avoid jeopardizing their daily work.

There are certainly many more civil society initiatives and volunteer movements active in the regions, which share borders with Luhansk and Donetsk regions and which accommodate most IDPs fleeing the conflict. ${ }^{31}$ However, the majority of these CSOs predominantly focus on the provision of humanitarian assistance rather than working on establishing dialogue and reconciliation. ${ }^{32}$ Yet, we are careful not to try to present our findings as generalizable "Ukrainian CSOs" experience or narrative. Rather, our goal is to outline different perceptions of the conflict and reconciliation, and to examine the extent to which these bottom-up narratives conform to, or diverge from, narratives employed by top-down sources.

Although everyday peace is generally understood as a "social practice," and more specifically comprising "practices and norms deployed, by individuals and groups," 33 it mainly draws attention to local actors' discourses and how they interpret and construct notions of conflict, peace and reconciliation. While this article discusses "imageries" and interpretations of conflict and peace, we do not argue that conflict is a mere social construction. Beyond doubt, conflict is

27 MediatEUr, “Dialogue Support Platform," accessed May 5, 2017, http://ukraine.dialoguesupport.org/ en/concepts/organizations.

28 International Center for Policy Studies, "Mapping of Dialogue Initiatives to Resolve Conflict in Eastern Ukraine," January 2015, 16, accessed April 14, 2017, http://icps.com.ua/assets/uploads/files/ mapping_of_dialogue_initiatives_eng_pdf. OSCE, "Civil Society and the Crisis in Ukraine." 
"real" in terms of hurt, pain, displacement, destruction and loss of human lives. Our sole ambition by drawing attention to narratives is to examine how local CSOs perceive the conflict and how they define reconciliation, and to examine if bottom-up narratives differ from those articulated by the Ukrainian government and international organizations. We place an emphasis on local CSOs narratives about the origins of the conflict, as well as the actors and factors they consider relevant for its resolution. Dominant top-down narratives of conflict often create a particular imagery of the "culprit" or untrustworthy "other" as the cause of the conflict (thus reproducing division rather than reconciliation) and greatly limit the options for "peace" (based on their own narrow political interests). Unearthing alternative bottom-up accounts on the causes and solutions of the conflict is therefore crucial to better understand the conflict resolution potential of local Ukrainian CSOs.

In order to examine local Ukrainian CSOs narratives, we largely draw on an ascriptive, bottom-up oriented research technique with few more structured elements. Researchers associated with the everyday peace project have cautioned against using established peace and conflict indicators to understand local actors' peacebuilding and reconciliation practices. Instead of "imposing indicators on other peoples," ${ }^{44}$ everyday peace research takes a different approach. It encourages local actors to "develop their own set of indicators of peace and change." 35

In the semi-structured interviews with the local CSOs, we first asked our respondents to provide us with their views on the conflict in Ukraine, their definition of the concept of reconciliation and their interpretation of how the activities/practices of their organizations contribute to reconciliation. We also asked them how far their organizations utilized knowledge of "external parties" to define and carry out their reconciliation activities. In the second part of the interviews, we confronted respondents with a list of more established indicators of conflict and reconciliation and asked them to prioritize the most relevant definitions in the context of the Ukraine conflict and their peacebuilding work.

While the open-ended inquiry in the first half of the interviews allowed us to unearth definitions of conflict and reconciliation that could potentially differ from orthodox indicators, the focus on a set of predefined indicators in the second half the interviews helped us establish some limited comparison between the perceptions of all seven CSOs.

Before presenting and examining our findings on the narratives of local Ukrainian CSOs using the transcripts of the respondents, we provide a brief overview of how, and the extent to which, dialogue and reconciliation emerged as a "new agenda" of post-Euromaidan local CSOs in Ukraine.

\section{Reconciliation and Dialogue as the "New Agenda" of Local CSOs in Ukraine}

The practice of mediation and dialogue facilitation existed in Ukraine before the 2014 conflict; however, it mostly operated in private sector, in courts and legal practices and was little known 
to the wider public. ${ }^{36}$ The use of role of a professional dialogue in other societal spheres was not taken as something important or necessary. Many of the interviewed CSOs representatives underline that if a proper dialogue and exchanges between Eastern and Western Ukraine had taken place at the very beginning of the country's independence gained in 1991, the present conflict might not have resulted in such severe consequences.

Nevertheless, the Euromaidan, the increasing alienation between pro-European and proRussian oriented demonstrators, and hostile actions of the Ukrainian police against unarmed demonstrators have identified a need for a dialogue. One form of dialogue was established at the level of political opposition leaders, another one - at the level of civil society, volunteers and people supporting the Euromaidan. As the situation in Eastern Ukraine escalated into the armed conflict causing further divisions among people supporting either sides of the conflict and then displacement and settlement in new communities of a significant number of people, the need for dialogue became even more important. It resulted in the emergence of a new agenda for civil society, including initiatives on establishing dialogue in Ukrainian communities aimed at reconciliation and peace building.

As many interviewed actors have identified, such initiatives were not taken by the government but rather remained a responsibility of Ukrainian civil society and existing networks of private sector mediators and dialogue facilitators. For example, a series of dialogues titled "Current Situation in Ukraine: Way to Find Mutual Understanding" were organized by the NGO "Foundation for Freedom" in December 2013.37 The initiative managed to hold several actions in Kyiv, Simferopol, Kharkiv, Donetsk and Lviv — to engage people with different opinions on the situation around Euromaidan. Another type of dialogue actions were promoted by civil society activities with the input of foreign experts in mediation and dialogue facilitation, for example a dialogue "Maidan-Berkut" facilitated by Dignity Space and expertise from the US-based Center of Non-Violent Communication. ${ }^{38}$

With many dialogue initiatives emerging during Euromaidan demonstrations and the escalation of conflict in Crimea and Donbas, dialogue culture remains a new development for Ukrainian society. Hence, most CSOs who are currently practicing dialogue and reconciliation activities have predominantly developed their skills by the necessity of practicing reconciliation for communities affected by the conflict.

It was observed that most of the CSOs practice dialogues and reconciliation activities for IDPs and members of receiving communities. Their activities vary from theatre performances, art workshops, day-clubs for women and children to dedicated sessions on how to adjust to the new community, discussions on human rights, participation in various trainings and exchanges of knowledge. Very few activities are focused on dialogue and reconciliation across the front line (between Ukrainian government-controlled and non-government-controlled territories of Donetsk and Luhansk regions). Only one civil society organization was identified as initiating

36 Kyselova, "Mediation Development in Ukraine: 1991-2015," 4-6.

37 Initiatives of Change International, "Dialogue on Searching for Mutual Understanding in the Ukrainian Society," February 2014, accessed April 14, 2017, http://www.iofc.org/dialoguesearching-understanding-ukrainian-society.

38 OSCE, "Civil Society and the Crisis in Ukraine," 8. 
communication between people living across the "borderline." Such communication takes place in online forums as well as in real life (dialogue marathons). However, this initiative and other similar initiatives encounter security threats when organizing dialogues, especially on the territories not controlled by the Ukrainian government, as participants could be caught by so-called authorities of self-proclaimed "Donetsk People's Republic" and the self-proclaimed "Luhansk People's Republic" and accused of betrayal or supporting the Ukrainian "enemies" (Interview 3). The same situation applies to government-controlled areas when certain contacts with people from the other side of the contact line are considered an act in support of "separatism" (Interview 1).

A common feature for the dialogue practicing CSOs is a lack of funding for their activities. Most local CSOs largely rely on foreign financial support and their own resources. While a large number of foreign assistance programs provide assistance for activities related to IDPs in conflict affected communities, there is little funding specifically targeting local CSOs promoting dialogue as a peacebuilding activity (Interview 3, 4, 5).

Several donors provide assistance to dialogue initiatives, in particular Conflict Pool Program of the British Embassy in Kyiv, Matra Social Transformation Program (the Netherlands), USAID, German Federal Minister for Foreign Affairs. While programs funded by the above mentioned actors aim at providing support to the local dialogue initiatives, the implementers of the programs are usually larger and more established organizations. ${ }^{39}$

CSOs that practice dialogue are usually small NGOs, consisting of a tiny group of dedicated persons. In a majority of cases, these are the people directly affected by the armed conflict who had to leave their homes in Donetsk and Luhansk regions of Ukraine. Their capacity and language skills for seeking and applying for foreign assistance programs are limited, which makes it challenging to ensure necessary funding that in most cases relies on personal enthusiasm of the CSOs members (Interviews 1, 3, 4, 5). None of the interviewed persons have identified that Ukrainian government is providing funding for dialogue activities. Following the most efficient practice of the Euromaidan, when people relied only on their own resources or actions by volunteers, most of grassroots initiatives mobilize all possible resources available in communities. Thus, local small and medium enterprises very often play a role of sponsors for various dialogue initiatives, providing facilities for meetings or necessary supply (Interviews 3, 4, 5).

The majority of CSOs practicing dialogue is located in and carries out their activities in government-controlled territories of Donetsk and Luhansk. The second largest CSOs community is based in border regions of Kharkiv, Dnipro and Poltava, as these regions accepted large number of IDPs. Kyiv as a capital remains, however, a place where most of the training and learning exchanges are taking place. Some CSOs are based in Kyiv and travel often to the East to practice their activities.

The network of professional mediators and dialogue facilitators and those who learned and dedicated their life to the process of reconciliation remains rather small relative to the territory of

39 Conflict Prevention Pool in Ukraine, "Peacebuilding Projects 2014-2015," accessed April 14, 2017, https://www.gov.uk/government/uploads/system/uploads/attachment_data/file/375216/CPP_ peacebuilding_Projects.pdf. 
Ukraine.$^{40}$ The National Association for Mediation of Ukraine (NAMU) lists about 100 registered members across the country. ${ }^{41}$ However, as the need to dialogue and reconciliation activities in Ukraine is increasing, the community of people working on this matter is likely to grow. Whilst some of the already established CSOs have reoriented their activities towards reconciliation, several new organizations have been founded to facilitate dialogue in their communities.

Therefore, it is possible to observe that there is indeed a new group of local Ukrainian civil society organizations, which emerged as a result of the Euromaidan, and have taken a role of establishing dialogue and promoting peace and reconciliation in Eastern Ukraine. They channel their actions to IDPs and hosting communities within the country, or to people living in conflictaffected areas across the frontline between government-controlled and occupied territories. They are small in numbers and lack capacity for large-scale projects, but being created by the people directly affected by the conflict, they are dedicated in their work and seek all possible means to achieve their goals of stabilization and normalization of relations between people and communities.

\section{CSOs Narratives on the Conflict in Ukraine}

In the following section, we present and examine our findings on the narratives of local Ukrainian CSOs on the origins of the Ukraine conflict and the factors and actors deemed relevant for its resolution.

\section{CSOs Narratives: The Origins of the Conflict}

When asked about the origins or causes of the current conflict in Ukraine, most CSOs representatives remain silent on the role of international actors in the conflict. Only one participant explicitly mentions involvement of Russia and the US, which he sees involved in a "proxy-conflict" over Ukraine (Interview 7). According to the same participant, the causes of the conflict are "competing spheres of influence, economic, strategic and military interests" (Interview 7). None of the CSOs representatives engaged in a discourse of "blaming" an external actor (or state) for the conflict. Rather, they showed a common recognition that the conflict was "complicated" because of a clash of "different positions" of "various participants" (Interviews 3, $4,6,7)$. To illustrate the complexity of the conflict, one participant remarked that "separatists think they fight Ukraine, Ukraine thinks it fights Russia and Russia thinks it fights — the West" (Interview 1). The European Union is not mentioned by any of the participants as a cause of the conflict. However, one CSO representative remarks that although EU elites "understand the conflict just fine" and are "surely aware" of the high level of corruption among the Ukrainian government elites, they "continue to work with these people without putting significant pressure on them" (Interview 1).

Whilst most CSOs remain vague on external actors' involvement in the conflict, they all emphasize the role of the Ukrainian state in their discussion of the origins and causes of the

$40 \quad$ Kyselova, "Mediation Development in Ukraine: 1991-2015," 8.

41 National Association for Mediation of Ukraine, accessed on April 14, 2017, http://namu.com.ua/. 
conflict. At a more general level, Ukrainian government elites are criticized for their "attitude of neglect" towards society (Interview 2), their entanglement in entrenched corruption (Interview 7) and lack of ethical/moral leadership (Interview 5, 7). With regards to the current conflict, most CSOs representatives point out that there has never been a state policy to foster "exchanges" or to find a "common ground" between the people from the "East" and the "West" (Interviews 1, 2, $3,5,7$ ), which has resulted in the "absence of any type of communication between communities in different regions of Ukraine" (Interview 6). For example, one participant explains that after the dissolution of the Soviet Union in 1991, "no dialogue was established between the East and West" of Ukraine and that as a result today "people from Donbas are afraid of Bandera and people from the West are afraid of people from the mines" (Interview 5). Several CSOs representatives conclude that the Ukrainian authorities are "not trustable" (Interview 3), that people have a "mistrust in government" (Interview 5), and that the elites are not "interested in resolving" (Interview 7) the conflict. As one participant explains:

Many [elites] benefit from the status quo. If the conflict were resolved ..., attention would shift more towards internal problems, which would put pressure on the elites to give up much of their existing perks, benefits and high quality of life (Interview 7).

Several participants also mention more structural causes of the conflict, for example the lack of social cohesion among the population in general (Interview 7), a significant "social gap" between communities in the East and the West of the country, and the absence of a middle class and social protection in the East in particular (Interview 2).

Many CSOs representatives also refer to the impact of "stereotypes," the "problem of generalizing people" and "enemy images" as key factors fueling the conflict by reducing peoples' commonalities, mutual understanding and "empathy" towards each other (Interviews 5, 6, 7).

\section{CSOs Narratives: Conflict Resolution and Reconciliation}

We also asked our respondents to reflect on the factors and actors deemed relevant for the resolution of the Ukraine conflict. In their responses, the CSOs representatives made a distinction between reconciliation as a goal and reconciliation as a process. ${ }^{42}$

Reconciliation as a goal. All CSOs representatives agree that reconciliation is a goal as well as a process, and that reconciliation in the context of the Ukraine conflict is first and foremost about exploring new relationships and interrupting established patterns of discourse. The focus is placed on rebuilding "peaceful discourse" (Interview 3), on "bringing people together" and uniting them around "something neutral" (Interview 5) and on "transforming the enemy image of another person by way of dialogue" (Interview 7). Rebuilding dialogue is deemed crucial to decrease the conflict by all respondents because dialogue "allows to understand others, develops

42 Valerie Rosoux, "Reconciliation as a Peace-Building process: Scope and Limits," in The SAGE

Handbook of Conflict Resolution, ed. by Jacob Bercovitch et al. (Los Angeles, CA; London; New Delhi:

SAGE, 2009), 543-63. 
trust" (Interview 3) and helps to "get rid of stereotypes" that are seen to have fueled the initial division and conflict (Interview 5 and 6). One participant, for example, explains that dialogue is the single most important aspect of reconciliation because it helps to re-create empathy between people, through establishing a human connection and "understanding of the life of the other," learning how other people have suffered and sharing how the conflict has impacted on each person involved from "personal experience rather than through generalizing" (Interview 7).

All CSOs representatives also agree that assigning blame is part of the cause of the conflict rather than a means of reconciliation. Many participants mention the importance of facilitating forgiving and express some reservations against the understanding of reconciliation as dealing with victims of political violence in the form of "legal or other measures" (i. e. war crimes tribunal), at least as long as the conflict remains at its present "hot stage." One respondent remarks that genuine reconciliation requires balanced measures of restorative and retributive justice, but that such processes must be carefully planned an implemented to ensure that they do not "backfire" (Interview 7). Most CSOs believe that the only realistic and feasible types of reconciliation in the present stage of the conflict are achieving an agreement to stop killing each other and exploring new relationships. The majority of respondents do not emphasize any other definitions of reconciliation or indicate that they only matter "after the end of the conflict" (Interview 5).

Overall, there is a clear consensus among CSOs representatives on an understanding of reconciliation as peaceful and truth-based/authentic personal dialogue. Dialogue in turn is seen to facilitate empathy and forgiveness on the basis of a better knowledge of the suffering of the "other" rather than a painless forgetting in the sense of leaving each side of the conflict retain its version of "the truth." An emphasis is placed on the future, rather than the past, with dialogue leading to the definition of "things in common with each other" (Interview 5), development of common interests and joint solutions (e. g. how to raise the quality of life or how to restore the country) (Interview 3) and "going back to normal life" (Interview 5).

Reconciliation as a process. Whereas all CSOs representatives agree on reconciliation as dialogue as a goal of their organizations' activities, there is some variation on the means and processes through which this goal can be achieved. Approximately half of our respondents identify people as the key actors in reconciliation. One CSO representative, for example, states that "every person is an actor for change" (Interview 5). The other half of participants stresses the important role of civil society organizations as "expert communities" in facilitating reconciliation among the people. In their opinion, CSOs are crucial in "initiating and supporting social demand for peace" (Interview 3). To illustrate their point, one participant makes a comparison with the failed peace-accord in Colombia where the "absence of systematic work with the population resulted in people's denial of the peace agreement" (Interview 3).

Several respondents also acknowledge that national policy and "sincere support for reconciliation from the high level" are required for ending the conflict and for reconciliation to become a sustainable process. Most CSOs representatives do, however, express cynicism when they discuss high-level support. Apart from the population's lack of trust in the political elites, respondents underline that "the least that the high level can do is not to hinder" bottom-up reconciliation efforts, suggesting that there is no real interest among national and international actors to end the conflict. 
When asked about the role of international organizations and the donor community, all CSOs representatives answer in a similar manner. Most are keen to mention their participation in trainings and workshops organized by the UN, the OSCE or donors associated with EU member states. Yet, when asked about the suitability or applicability of "outside" expert knowledge or reconciliation models, most respondents choose not to answer the question at all, without providing a reason. Those who did answer the question explained diplomatically that "we work in different fields with different means" (Interview 5) or stated outright that the relationship between civil society and international donors is "flawed" (Interview 7). Remarkably, none of the CSOs representatives identified peacebuilding efforts by the international community (organizations, states, donors) as important or relevant in the process of reconciliation in Ukraine.

\section{Local Ukrainian CSOs: A Promising Agency for Reconciliation}

Our respondents' narratives on the origins of the Ukraine conflict demonstrate that CSOs clearly recognize the complexity of the conflict. There is noticeable reluctance to repeat or reinforce dominant top-down narratives of regional powers in which the "other" is blamed for the conflict, and in which divisions between people rather than commonalities are underlined. Most respondents agree, however, that Ukrainian governments in the past have failed to foster exchanges or to find a common ground between the people from the "East" and the "West." As a result, any type of communication between communities in different regions of Ukraine has been absent.

Having identified the lack of understanding between people as a key factor affecting the conflict, local CSOs strongly emphasize the unity among communities, the deconstruction of negative images of the "other" and the rebuilding of empathy as the leading goals of their dialogue and reconciliation activities. To achieve these goals, CSOs highlight the crucial role of people and/or local CSOs in bringing about dialogue and reconciliation. Local CSOs therefore yield a significant promise as agency in fostering reconciliation.

\section{Top-down Narratives of Conflict and Reconciliation}

In this part, we examine the main narratives on the causes of the Ukraine "conflict" and options for "reconciliation" articulated by (i) key international and regional organizations, (ii) the Ukrainian government and (iii) the Russian government. By way of conclusion, we compare these top-down narratives on the conflict and its resolution to the bottom-up narratives of local Ukrainian CSOs.

\section{Conflict Narratives of International Organizations}

International and regional organizations have been actively involved in the assessment and settlement of the Ukraine conflict since January 2014. Whereas the United Nations Security Council (UNSC) has by and large been paralyzed due to Russia's repeated use of its veto power 
to block resolutions on the Ukraine conflict, ${ }^{43}$ the Organization for Security and Cooperation in Europe (OSCE) and the European Union have taken a significant number of practical actions to support the resolution of the conflict.

\section{The OSCE's Narrative of the Conflict}

The OSCE has engaged in multiple efforts for the observation and settlement of the Ukraine conflict, including, inter alia, deployment of a special envoy to Ukraine conducting bilateral talks with involved parties, a human rights assessment mission, as well as a Special Monitoring Mission (SMM) tasked with monitoring the implementation of the Minsk peace protocol. The OSCE sees its main role in supporting the efforts of the Trilateral Contact Group on Ukraine to "create the conditions for a sustainable ceasefire ... putting an end to violence in Eastern Ukraine." ${ }^{44}$ The Trilateral Group includes representatives from Ukraine, Russia and the OSCE to facilitate a diplomatic resolution to the war in Eastern Ukraine. SMM is tasked to play a leading role in "assisting Ukrainian authorities and local communities" 45 in the implementation of the peace protocol. Part of the mission's mandate also pertains to establishing "contact with local, regional and national authorities, civil society, ethnic and religious groups, and members of the local population." 46 However, the impact of the mission on facilitating dialogue has yielded rather limited results, due to the lack of a mission-wide strategy and member states' neglect of dialogue facilitation in Ukraine. ${ }^{47}$

Rather than engaging in a narrative on the origins of the conflict, the OSCE has thus placed an emphasis on supporting dialogue within the "top-down" mechanism of the Trilateral Group, and the monitoring of the ceasefire, which is viewed as a precondition for achieving the resolution of the Ukraine conflict. The OSCE's Project Coordinator in Ukraine (PCU) has facilitated several dialogue forums between central government and local communities (local authorities, civil society, business representatives, etc.) in Eastern Ukraine, discussing the issues of demining, social and economic development. ${ }^{48}$ While facilitating dialogue forums, the OSCE's support for local bottom-up reconciliation efforts has, however, not been a priority in the organization's narratives on or activities in support of the resolution of the conflict.

43 Alena Douhan, "International Organisations and Settlement of the Conflict in Ukraine," Heidelberg Journal of International Law 75.1 (2015), 195-214.

44 OSCE Permanent Council, "Declaration on the Tragic Crash of the Malaysia Airlines Flight MH17 in Ukraine," July, 18, 2014, 1.

45 European Union External Action Service, "Geneva Statement on Ukraine, 140417/o1," April 17, 2014.

46 OSCE, “Decision No 1117 Deployment of an OSCE Special Monitoring Mission to Ukraine," PC Journal 991, March 21, 2014, 1.

47 Sylvia Rognvik, "Dialogue Facilitation," 1-2.

48 OSCE Project Co-ordinator in Ukraine, "Demining, Social Issues, Business Climate and Infrastructure Discussed at OSCE-supported Dialogue Forum in Mariupol, Eastern Ukraine," March 23, 2017, accessed May 8, 2017, http://www.osce.org/ukraine/229641. 


\section{The EU's Narrative of the Conflict}

The Heads of State and Government have elaborated the European Union's narrative on the Ukraine conflict in successive European Council Conclusions as well as Statements. The EU has taken a clear stance in the early stages of the conflict, declaring that the annexation of Crimea constitutes a "clear violation of Ukraine's sovereignty and territorial integrity by acts of aggression by the Russian armed forces" and this a "breach of Russia's international obligations and commitments." ${ }^{49}$ With respect to the violence erupting in the eastern provinces of Ukraine in spring 2014, the EU was initially cautious in its assessment of the conflict's origins, calling for an end to violence and tensions and asking Russia to "use its leverage on the armed separatists to de-escalate the situation in Eastern Ukraine." ${ }^{50}$ Half a year later in August 2014, the Council had already adopted a clearer position on the role of Russia in the conflict, stating that it "condemns the increasing inflows of fighters and weapons from the territory of the Russian Federation into Eastern Ukraine," 51 followed by a statement issued in January 2015, in which the EU notes "evidence of continued and growing support given to the separatists by Russia, which underlines Russia's responsibility." 52 In its narrative on the origins of the conflict, the EU thus clearly identifies the Russian Federation as a key player fueling the conflict.

In line with this assessment of the conflict, the EU has adopted a series of restrictive measures against the Russian Federation, including ceasing of negotiations on visa issues and termination of financial assistance, alongside sanctions on a number of individuals and companies from Russia. In parallel, the EU has underlined the importance of multilateral mechanisms to "build confidence between the parties" and engage the governments of Ukraine and Russia in direct negotiations. ${ }^{53}$ The other key measures often proposed by the EU to resolve the conflict involve support for Ukraine. An "immediate priority" was to "restore macroeconomic stability through sound fiscal, monetary and exchange rate policies," ${ }^{44}$ whereas later an emphasis was placed on signing the Association Agreement and in particular the Deep and Comprehensive Free Trade Agreement and the implementation of structural economic reforms with International Monetary Fund support. ${ }^{55}$

The present situation of the general population in the conflict areas rarely features in the EU's official rhetoric. The humanitarian impact of the conflict is only explicitly mentioned in declarations from August 2014 onwards and internally displaced people and refugees are

49 Council of the European Union - Foreign Affairs Council, "EU Condemns Russia's Actions in Ukraine," Brussels, March 3, 2014, 1.

$5^{\circ}$ Council of the European Union, "Statement of the Heads of State or Government on Ukraine," Brussels, May 27, 2014, 2.

$5^{1} \quad$ European Council, "Conclusions," Brussels, August 30, 2014, 3.

$5^{2}$ European Council, "Statement of the Heads of State or Government," Brussels, January 26, $2015,1$.

53 European Council, "Statement of the Heads of State or Government on Ukraine," Brussels, March 6, 2014, 2.

54 European Council, "Statement of the Heads of State or Government on Ukraine," 3.

55 Council of the European Union, "Statement of the Heads of State or Government on Ukraine," Brussels, May 27, 2014, 2. 
not mentioned until the European Council Conclusions of 29 January 2015, in which the EU pledges its "commitment to support the most vulnerable population affected by the conflict." 56 Reconciliation at the local or civil society levels does not feature in any of the major declarations and statements by the EU Heads of State or Governments.

The EU's narrative on the conflict is therefore almost exclusively focused on states and top-down conflict resolution mechanisms. The Russian Federation is identified as a key driver of the conflict and accordingly, punitive measures against Russia play a significant role in the EU's proposed solution to the conflict. At the same time, the EU emphasizes dialogue between Ukraine and Russia in a multilateral setting. The local level or bottom-up processes of reconciliation play no role in the EU's narrative.

Much of the EU's (and other international donors') financial assistance to Ukraine is based on the Recovery and Peacebuilding Assessment (RPA), ${ }^{57}$ a study carried out jointly by the EU, UN, and the World Bank and published in spring 2015. The assessment explicitly aims at providing a common narrative of the Ukraine conflict and the required peacebuilding efforts shared by the three international organizations, and with the purpose of providing a common approach to the conflict by the international community.

The report remains rather vague on the causes of the conflict but explains that:

...the conflict has significantly deteriorated levels of social cohesion, trust and cooperation throughout the country, which were already eroded from years of divergent and politically charged narratives about history, language and patriotism. ${ }^{58}$

The report places a clear emphasis on "economic distress," which is defined as a key factor that has led to the erosion of social cohesion. ${ }^{59}$ According to the report, the Donbas region had already faced "significant long-term challenges related to poverty, demography, and its economic structure." The conflict in Eastern Ukraine is perceived to have had a significant impact on human welfare and on social and economic conditions in the East. ${ }^{60}$ In addition, the "absence of elements of governance that could manage instability" is regarded as a problem. ${ }^{61}$

Having identified economic decline and the lack of governance as key sources of social conflict, the report goes on to define a set of measures to reduce social tensions and rebuild trust and cooperation among the population. The majority of the proposed measures focus on economic recovery, such as the restoration of critical infrastructure and economy. One measure

56 Council of the European Union — Foreign Affairs Council, "Council Conclusions on Ukraine," Brussels, January 29, 2015, 3 . World Bank, "Recovery and Peace Building Assessment: Analysis of Crisis Impacts and Needs in Eastern Ukraine: Synthesis Report," March 2015, accessed March 18, 2017, http://documents. worldbank.org/curated/en/879011468188335375/Synthesis-report. 
aims at strengthening "social resilience, peacebuilding and community security." ${ }^{2}$ However, despite the rhetoric on "bringing various groups together to overcome differences and grievances through dialogue," 63 the only concrete actions proposed in the report for this measure include trainings of local CSOs and think tanks to "monitor the situation and provide recommendations," trainings for civil society activists on gender-sensitive post-conflict policy and capacity-building trainings for women's NGOs. ${ }^{64}$

Conflict Narratives of International Organizations: Prioritizing the Top-Down Approach

The narrative of leading international (and regional) organizations on the origins of the Ukraine conflict and the measures to be taken to resolve the conflict has clearly been dominated by either blaming and shaming the "other" (the EU's focus on Russia's role and responsibility in fueling tensions in Eastern Ukraine) or a top-down approach to conflict resolution focused on fostering dialogue between Ukraine and Russia in a multilateral setting (EU and OSCE). In addition, the EU and other international donors have placed a key emphasis on Ukraine's economic recovery and reform to overcome social tensions. These efforts are based on contemporary neoliberal guided peacebuilding approaches. Their effect on tackling social-economic grievances however, remains contested. ${ }^{65}$ Bottom-up local reconciliation rarely features in these narratives. If local CSOs are mentioned, their role is by and large reduced to monitoring and reporting rather than as a legitimate agency in fostering dialogue and peace.

\section{Conflict Narratives of the Ukrainian Government}

The Ukrainian government and media frequently state that the unrest in Ukraine was manufactured by Russia. They have consistently accused Russia of being a provocateur, and of controlling the anti-government groups behind the scenes. ${ }^{66}$ The annexation of Crimea is viewed as illegitimate and illegal. Following the start of the war in Donbas, the Ukrainian government and some media described the armed groups of the self-proclaimed so-called Donetsk People's Republic (DPR) and Luhansk People's Republic (LPR) as "terrorists" and "separatists" and referred to the military operation against the DPR and LPR as an "anti-terrorist" operation. ${ }^{67}$

The official position of the Ukrainian government expressed by the President Poroshenko and various high-level officials is that the only solution to the conflict in Eastern Ukraine and restoration of the country's territorial integrity is a politic-diplomatic one, in particular through

62 World Bank, "Recovery and Peace Building," 23-24.

63 World Bank, "Recovery and Peace Building," 34.

64 World Bank, "Recovery and Peace Building," 66.

65 James Ahearne, "Neoliberal Economic Policies and Post-Conflict Peace-Building: A Help or Hindrance to Durable Peace?" POLIS Journal 2 (2009): 1-44.

66 John Fund, “Ukraine's May Day Danger," National Review, May 1, 2014, accessed March 9, 2017, http:// www.nationalreview.com/article/377006/ukraines-may-day-danger-john-fund.

67 Elizabeth Piper, “Ukraine Ready for Talks with the East, not with 'Terrorists," Reuters News, March 8, 2014, accessed March 9, 2017, http://news.trust.org//item/20140508055311-ce4V7; and Law of Ukraine on "Temporary Actions for the Period of Implementation of Anti-Terrorist Operation," No 1669-VII, September 2, 2014, accessed May 8, 2017, http://zakon3.rada.gov.ua/laws/show/1669-18. 
the full implementation of the Minsk Agreement. ${ }^{68}$ In the annual address to the Parliament on internal and external situation in 2016, Petro Poroshenko underlines that this process will be long and difficult:

The process of real, not formal restoration of territorial integrity, reintegration of residents of the occupied territories of Donbas into Ukraine, return of the Ukrainian sovereignty to Donbas will be difficult, painful and long. ${ }^{9}$

While the only solution to the conflict lies in political means, the plan of the government on the restoration of peace in Donbas focuses on strengthening the defensive military capacities of the Ukrainian army in order to withstand the external attacks. ${ }^{70}$ From the point of view of the Ukrainian President, continuation and strengthening of Western sanctions against Russia is another element of forcing the "aggressor state" to implement the Minsk Agreement, which would pave the way to the resolution of the conflict, as it will at the same time make it financially difficult to support separatists in the self-proclaimed "DPR" and "LPR."71

From the Ukrainian government's point of view, the resolution of the conflict also lays within the implementation of reforms, in particular the fight against corruption, reforms of the judiciary, law enforcement and decentralization process. ${ }^{72}$ President Poroshenko mentions that support from international community and visa free regime with the EU countries would become "...also an element of peaceful settlement in Donbas and de-occupation of Crimea." 73

With the reference to the Deputy Minister of Temporarily Occupied Territories and IDPs, Ukrainian media informed that on 31 August 2016 the Cabinet of Ministers of Ukraine adopted a Concept of the Program for the Restoration and Peaceful Development of Eastern Regions of Ukraine. According to the document, the plan includes action in three key areas:

- Restoration of infrastructure and social services — with the estimated need of 1257,7 mln USD;

- Restoration of economy - estimated need 135,5 mln USD;

68 President of Ukraine, "Attempts to Disrupt Peace Process is Irresponsible with Regard to State and Will Lead only to Continuation of Occupation of Part of Donetsk and Luhansk Regions," May 20, 2016, accessed April 14, 2017, http://www.president.gov.ua/en/news/prezident-namagannya-zirvatimirni-procesi-bezvidpovidalno-p-37139.

69 President of Ukraine, "Shchorichne poslannia Prezydenta do Verkhovnoi Rady [Annual Address of the President to the Verkhovna Rada]," September 6, 2016, accessed April 14, 2017, http://www. president.gov.ua/en/news/shorichne-poslannya-prezidenta-do-verhovnoyi-radi-pro -vnutri-38o77. President of Ukraine, "Shchorichne poslannia Prezydenta do Verkhovnoi Rady." President of Ukraine, “The World, Europe and Ukraine: Storms of Changes," September 16, 2016, accessed April 14, 2017, http://www.president.gov.ua/en/news/vistup-prezidenta-petra-poroshenkana-13-j-shorichnij-zustri-38163. 
- Social sustainability, peacebuilding, and citizens' security—estimated need $126,8 \mathrm{mln}$ USD. ${ }^{74}$

The last aspect of the concept focuses on rebuilding trust between people, creation of social unity, facilitation of cultural dialogue and tolerance, support to the development of civil society and citizen's initiatives and psychological assistance to people. The concept, however, lacks concrete actions and mechanisms of achieving the outlined goals, and it relies largely on international technical assistance.

In summary, the narrative of the Ukrainian government is dominated by an understanding of peace as geopolitics, and the return of territory under its control, rather than reconciliation and rebuilding of trust between people. On the few occasions that the government refers to reconciliation between people are in the context of international aid programs. But as the previous section highlighted, the international community's support for civil society organizations is by and large limited to trainings, monitoring and reporting.

\section{Conflict Narrative of the Russian Government}

The Russian media consistently portrays the conflict in Ukraine as having been instigated by the post-Yanukovych Ukrainian government, and represented Euromaidan as being controlled by "ultranationalist," "fascist," "neo-Nazi," and "anti-Semitic" groups. The revolution was depicted as a violent "coup d'état" initiated by the West in order to overthrow an elected government of Viktor Yanukovych.

For the Russian government, Crimea's return to Ukraine is not even on the agenda, while Russia's position on Donbas provides for variations of discourse. From the Russian point of view, escalation of the conflict is caused by the Ukrainian volunteer battalions and by Ukraine's non-compliance with the Minsk Agreements. ${ }^{75}$ Russia sees the important step in the resolution of the conflict in the decentralization process and conduct of local elections in the territory of Donbas. ${ }^{76}$

While the Russian government clearly engages in constructing Ukraine as the party to blame for the conflict, including the construction of Ukraine and its people as the threatening "other," a small number of bottom-up dialogue initiatives are organized by independent Russian CSOs. One example is the project "Dialogues: Ukraine - Russia," initiated by a Russian mediator between Ukrainian and Russian representatives of various professions and occupations within

74 "Peaceful Initiative: How the Government Plans to Restore Donbas," Ukrainian Information Agency $(R B K)$, August 31, 2016, accessed April 14, 2017, https://daily.rbc.ua/rus/show/mirnaya-initsiativapravitelstvo-sobiraetsya-147264015o.html. Irina Alksnis, "Po probleme Ukrainy i Donbassa Moskva vylozhyla karty na stol [On the Problem of Ukraine and Donbas, Moscow Put the Cards on the Table]," February 12, 2017, accessed April 15, 2017, https://vz.ru/politics/2017/2/12/857694.html.

76 "Lavrov Thinks that Ukraine has to Go Back to the Idea of Decentralisation," Ria News, February 12, 2017, accessed April 15, 2017, https://ria.ru/world/20170212/1487760395.html. 
the project "Initiating the Participatory National Dialogue in Ukraine." 77 Therefore, while the official Russian government's narrative does not provide for a role of civil society to engage in peacebuilding activities, a small number of independent grassroots initiatives exist in Russian society, which seek to foster the process of reconciliation.

\section{Conclusion}

In this article, we analyzed the role of local Ukrainian civil society organizations in fostering dialogue and reconciliation in Eastern Ukraine. Most scholarly works on the Ukraine conflict are state-centric. An exclusive focus is placed on the roles and interests of major regional and international powers, such as the Russian Federation, the United States, the North Atlantic Treaty Organization or the European Union and its member states. Research on sub-state actors, such as civil society, as meaningful and legitimate players in the conflict and its resolution, is scarce. This surprises in light of the steady increase of Ukrainian civil society organizations, which have embraced reconciliation as a new agenda in the post-Euromaidan period.

To examine the role of local Ukrainian CSO's in fostering reconciliation, we drew on the "everyday peace" approach. The concept of everyday peace recognizes the important role of local CSOs in peacebuilding processes. Researching everyday peace practices involves moving away from statist research agendas and traditional (static) views on conflict, security and reconciliation. Dominant top-down narratives of conflict often create a particular imagery of the "culprit" or untrustworthy "other" as the cause of the conflict (thus reproducing division rather than reconciliation) and greatly limit the options for "peace" (based on their own narrow political interests). Unearthing alternative bottom-up accounts on the causes and solutions of the conflict is therefore crucial to better understand the conflict resolution potential of local Ukrainian CSOs.

We examined the narratives of seven local Ukrainian CSOs on the origins of the Ukraine conflict and the factors and actors deemed relevant for its resolution. Having identified the lack of understanding between people as a key determinant affecting the conflict, local CSOs strongly emphasized the unity among communities, the deconstruction of negative images of the "other" and the rebuilding of empathy as the leading goals of their dialogue and reconciliation activities. In order to achieve these goals, CSOs highlighted the crucial role of people and/or local CSOs in bringing about dialogue and reconciliation.

In contrast, the narratives of key international and regional organizations clearly reveal a top-down approach to conflict resolution focused on fostering dialogue between the governments of Ukraine and Russia in a multilateral setting (EU and OSCE). In addition, the EU and other international donors have placed a key emphasis on Ukraine's economic recovery and reform as key measures to reducing social tensions (economic approach to peacebuilding). Bottom-up local reconciliation rarely features in these narratives. If local CSOs are mentioned, their role is by and large reduced to monitoring and reporting rather than as a legitimate agency in fostering dialogue and peace. At the same time, the Ukrainian and Russian governments continue to engage in 
confrontational discourses, underlining differences and division between their countries and populations.

The main point of this article is that a different kind of narrative of the Ukraine conflict and its resolution emerges if the analytical focus is placed on local CSOs. We found that local bottom-up narratives and the narratives constructed by top-down actors such as governments or international organizations clearly differ in terms of content. The top-down narratives of the Ukrainian and Russian governments tend to legitimize and reconfirm the status quo of the conflict (constructing the other as the "culprit" or "enemy"), while key international organizations reconfirm the primacy of states (aided by multilateral cooperation mechanisms) and/or the authority of the (neo-)liberal economic paradigm.

Local CSOs do not challenge these top-down narratives directly, but they certainly introduce many alternative pathways to fostering dialogue and reconciliation in Ukraine, such as rebuilding understanding, trust, respect and empathy among people. Such efforts of "rehumanising the other" 78 are (and will be) quintessential processes for achieving sustainable peace in Ukraine and thus ought to receive much greater attention from policy-makers and analysts.

\section{Bibliography}

Ahearne, James. "Neoliberal Economic Policies and Post-Conflict Peace-Building: A Help or Hindrance to Durable Peace?" POLIS Journal, 2, 2009, 1-44.

Alksnis, Irina. "Po probleme Ukrainy i Donbassa Moskva vylozhyla karty na stol [On the Problem of Ukraine and Donbas, Moscow Put the Cards on the Table]." February 12, 2017. Accessed April 15, 2017. https://vz.ru/politics/2017/2/12/857694.html.

Applebaum, Anne. "War in Europe Is Not a Hysterical Idea." Washington Post, August 29, 2014. Accessed December 17, 2016. http://www.washingtonpost.com/opinions/anneapplebaum-war-in-europe-is-not-a-hysterical-idea/2014/o8/29/815f29d4-2f93-11e4bbgb-997aeg6fad33_story.html.

Council of the European Union-Foreign Affairs Council. "Council Conclusions on Ukraine." Brussels, January 29, 2015.

Council of the European Union-Foreign Affairs Council."EU condemns Russia's Actions in Ukraine." Brussels, March 3, 2014.

Council of the European Union. "Statement of the Heads of State or Government on Ukraine." Brussels, May 27, 2014.

Douhan, Alena. "International Organizations and Settlement of the Conflict in Ukraine." Heidelberg Journal of International Law 75.1 (2015): 195-214.

Dragneva-Lewers, Rilka, and Kataryna Wolczuk. Ukraine Between the EU and Russia: The Integration Challenge. Houndmills; Basingstoke; New York: Palgrave Macmillan, 2015.

European Council. "Conclusions." Brussels, August 30, 2014.

European Council. "Statement of the Heads of State or Government on Ukraine." Brussels, March 6, 2014.

78 Jody Halpern and Harvey M. Weinstein, "Rehumanizing the Other: Empathy and Reconciliation," Human Rights Quarterly 26.3 (2004): 561-83. 
European Council. "Statement of the Heads of State or Government." Brussels, January 26, 2015. European Union External Action Service. "Geneva Statement on Ukraine 140417/o1." April 17, 2014. Fund, John. "Ukraine’s May Day Danger." National Review, May 1, 2014. Accessed March 9, 2017. http://www.nationalreview.com/ article/3770o6/ukraines-may-day-danger-john-fund.

Goetschel, Laurent, and Tobias Hagmann. "Civilian Peacebuilding: Peace by Bureaucratic Means? Analysis." Conflict, Security \& Development 9.1 (2009): 55-73.

Halpern, Jody, and Harvey M. Weinstein. "Rehumanizing the Other: Empathy and Reconciliation." Human Rights Quarterly 26.3 (2004): 561-83.

Humanitarian Bulletin Ukraine 15 (October-December 2016). Accessed March 16, 2017. http:// reliefweb.int/report/ukraine/humanitarian-bulletin-ukraine-issue-15-1-october-31december-2016.

“Humanitarian Needs Overview 2016." November 2015. Accessed March 16, 2017. http://www. globalprotectioncluster.org/_assets/files.

Ikenberry, G. John. "The Illusion of Geopolitics:The Enduring Power of the Liberal Order." Foreign Affairs 93 (2014): 80.

International Centre for Policy Studies. "Mapping of Dialogue Initiatives to Resolve the Conflict in Ukraine." January 2015. Accessed December 12, 2016. http://icps.com.ua/assets/uploads/ files/mapping_of_dialogue_initiatives_eng_.pdf.

Kazharski, Aliaksei, and Andrey Makarychev. "Suturing the Neighborhood? Russia and the EU in Conflictual Intersubjectivity." Problems of Post-Communism 62.6 (2015): 328-39.

Kyselova, Tatiana. "Mediation Development in Ukraine:1991-2015." Working Paper. January 2016. Accessed on May 8, 2017. https:/www.academia.edu/20286554/Mediation_Development_ in_Ukraine_1991-2016.

"Lavrov Thinks that Ukraine Has to Go Back to the Idea of Decentralisation." Ria News, February 12, 2017. Accessed April 15, 2017. https://ria.ru/world/20170212/1487760395.html.

Law of Ukraine "On Temporary Actions for the Period of Implementation of Anti-Terrorist Operation.” № 1669-VII. September 2, 2014. Accessed May 8, 2017. http://zakon3.rada.gov. ua/laws/show/1669-18.

Lederach, John Paul. Preparing for Peace: Conflict Transformation Across Cultures. Syracuse, NY: Syracuse University Press, 1995.

Mac Ginty, Roger, and Oliver P. Richmond. "The Local Turn in Peace Building: A Critical Agenda for Peace." Third World Quarterly 34.5 (2013): 763-83.

Mac Ginty, Roger, and Pamina Firchow. "Top-Down and Bottom-Up Narratives of Peace and Conflict." Politics 36.3 (2016): 308-23.

Mac Ginty, Roger. “Everyday Peace: Bottom-up and Local Agency in Conflict-Affected Societies.” Security Dialogue 45.6 (2014): 548-64.

MediatEUr. “Dialogue Support Platform.” Accessed May 5, 2017. http://ukraine.dialoguesupport. org/en/concepts/organizations.

"No surrender." Kyiv Post, September 11, 2014. Accessed March 9, 2017. https://www.kyivpost.com/ article/opinion/editorial/no-surrender-364338.html.

Office of the United Nations High Commissioner for Human Rights, HRMMU. "Report on the Human Rights Situation in Ukraine: 16 February to 15 May 2016.” Accessed March 16, 2017. http://www.ohchr.org/Documents/Countries/UA/ Ukraine_14th_HRMMU_Report.pdf. 
OSCE Permanent Council. "Declaration on the Tragic Crash of the Malaysia Airlines Flight MH17 in Ukraine." July, 18, 2014.

OSCE Project Co-ordinator in Ukraine. "Demining, Social Issues, Business Climate and Infrastructure Discussed at OSCE-Supported Dialogue Forum in Mariupol, Eastern Ukraine.” March 23, 2017. Accessed May 8, 2017. http://www.osce.org/ukraine/229641.

OSCE. "Decision No. 1117 Deployment of an OSCE Special Monitoring Mission to Ukraine." PC Journal No. 991. March 21, 2014.

OSCE. Thematic Report "Civil Society and the Crisis in Ukraine." February 11, 2015. Accessed on April 25, 2017. http://www.osce.org/ukraine-smm/141046?download=true.

Pasquienelly, Giulia. "Peacebuilding in Ukraine: A Long Way to Go." May 7, 2016. Agency for Peacebuilding. Accessed December 15, 2016. http://www.peaceagency.org/en/2016/o5/o7/ peacebuilding-in-ukraine-a-long-way-to-go.

"Peaceful Initiative: How the Government Plans to Restore Donbas", Ukrainian Information Agency (RBK), August 31, 2016. Accessed April 14, 2017. https://daily.rbc.ua/rus/show/ mirnaya-initsiativa-pravitelstvo-sobiraetsya-147264015o.html.

Piper, Elizabeth. "Ukraine Ready for Talks with the East, not with 'Terrorists." Reuters News, March 8, 2014. Accessed March 9, 2017. http://news.trust.org//item/20140508055311-ce4V7.

President of Ukraine. "Attempts to Disrupt Peace Process is Irresponsible with Regard to State and Will Lead Only to Continuation of Occupation of Part of Donetsk and Luhansk Regions." May 20, 2016. Accessed April 14, 2017. http://www.president.gov.ua/en/news/prezidentnamagannya-zirvati-mirni-procesi-bezvidpovidalno-p-37139.

President of Ukraine. "Shchorichne poslannia Prezydenta do Verkhovnoi Rady [Annual Address of the President to the Verkhovna Rada]." September 6, 2016. Accessed April 14, 2017, http:// www.president.gov.ua/en/news/shorichne-poslannya-prezidenta-do-verhovnoyi-radi-pro -vnutri-38077.

President of Ukraine. "The World, Europe and Ukraine: Storms of Changes." September 16, 2016. Accessed April 14, 2017. http://www.president.gov.ua/en/news/vistup-prezidenta-petraporoshenka-na-13-j-shorichnij-zustri-38163.

Pridham, Geoffrey. "EU/Ukraine Relations and the Crisis with Russia, 2013-14: A Turning Point." The International Spectator 49.4 (2014): 53-61.

Rieker, Pernille, and Kristian Lundby Gjerde. "The EU, Russia and the Potential For DialogueDifferent Readings of the Crisis in Ukraine." European Security 25.3 (2016): 304-25.

Rognvik, Sylvia. "Dialogue Facilitation." Norwegian Centre for Human Rights. May 2016. Accessed March 4, 2017. http://www.jus.uio.no/smr/english/about/programmes/nordem/ publications/nordemthematicpaper_oscesmm_dialogue-facilitation.pdf.

Rosoux, Valerie. "Reconciliation as a Peace-Building Process: Scope and Limits." In The SAGE Handbook Of Conflict Resolution, edited by Jacob Bercovitch et al., 543-63. Los Angeles, CA; London; New Delhi: SAGE, 2009.

Schmidt-Felzmann, Anke. "The Breakdown of the EU's Strategic Partnership with Russia: From Strategic Patience Towards a Strategic Failure." Cambridge Review of International Affairs 29.1 (2016): 99-127. 
Strasheim, Julia. "Domestic Explanations for War and Peace in Ukraine." GIGA Working Paper 287 (2016): 1-22.

UNHCR Protection Cluster Ukraine, "Peacebuilding and Reconciliation in Ukraine." July 2016. Accessed January 15, 2017. http://unhcr.org.ua/attachments/article/317/Peacebuilding\%20 And\%2oReconciliation_Guidance\%2oNote_Final-ENG.pdf.

World Bank. "Recovery and Peacebuiding Assessment: Analysis of Crisis Impacts and Needs in Eastern Ukraine: Synthesis report." March 2015. Accessed March 18, 2017. http://documents. worldbank.org/curated/en/879o11468188335375/Synthesis-report.

Ganna Bazilo holds MA in European Studies from the Maastricht University and MA in European Political and Administrative Studies from the College of Europe. Her expertise covers the areas of civil society development, capacity-building, EU cooperation programmes with Ukraine and Eastern Partnership countries. Ganna has worked in the European Parliament (EU-Ukraine Parliamentary Association Committee), Twinning project on "Support to the Development of Social Services System in Ukraine" and in the Parliamentary Assembly of the Council of Europe in Strasbourg. She is currently Coordination and Cooperation Officer at the EU Advisory Mission in Ukraine (EUAM).

Dr. Giselle Bosse is Assistant Professor (with tenure) and Co-Director of the MSc European Studies (Research) at Maastricht University (Netherlands). She is also Visiting Professor at the College of Europe in Bruges. Her research focuses on the EU' s policies towards Eastern Partnership countries. In 2012, she was awarded a VENI Research Grant from the Netherlands Organisation for Scientific Research (NWO) for her project on Explaining Europe's failure to deal with autocratic regimes: Which actors make and break effective democracy promotion? (€250.000; Ref 451-12-015). Giselle has published her research inter alia in the Journal of Common Market Studies, Geopolitics, Europe-Asia Studies, Cooperation and Conflict and with Manchester University Press. She frequently presents her work at leading think tanks in Europe and has contributed to several commissioned studies for EU institutions and think tanks. 


\section{ANNEX I: Interviews with CSOs (background information)}

Note: The list of CSOs below is ordered alphabetically and does not correspond to the numbering in the main text. Our respondents have requested a degree of anonymity to minimize risks in carrying out their activities.

\begin{tabular}{|c|c|c|}
\hline NAME & LOCATION & INFORMATION \\
\hline Cultural Dialogue & $\begin{array}{l}\text { Kremenchuk, } \\
\text { Poltava region }\end{array}$ & $\begin{array}{l}\text { Cultural Dialogue is facilitating dialogues and community } \\
\text { development through social transformation and intercultural } \\
\text { dialogue. Activities such as workshops, theatres, etc. are organised } \\
\text { at the cultural space "Adapter." CSO works with IDPs, women, } \\
\text { religious and cultural communities. It was established as a result } \\
\text { of the conflict in Eastern Ukraine. The members of Cultural } \\
\text { Dialogue are IDPs and local persons (receiving community). The } \\
\text { activities of NGOs are mostly self-funded and rely on community } \\
\text { support. }\end{array}$ \\
\hline
\end{tabular}

Donbas Dialogue Sviatohirsk,
Donetsk region $\begin{aligned} & \text { This CSO organizes inter-community dialogues between people } \\ & \text { living across the front line with the use of crowdsourcing, online } \\ & \text { and offline dialogues. The aims of their activities are to find } \\ & \text { topics for dialogues and to create professional circles of dialogue } \\ & \text { facilitators. Since autumn } 2014 \text { they conducted two dialogue } \\ & \text { marathons, the third one is planned for spring 2017. Donbas } \\ & \text { Dialogue was established after the Revolution of Dignity with the } \\ & \text { escalation of the conflict in Eastern Ukraine. The core members } \\ & \text { consist of several persons. Learning process and some activities } \\ & \text { were supported by Nansen Center for Peace and Dialogue } \\ & \text { (Norway). }\end{aligned}$

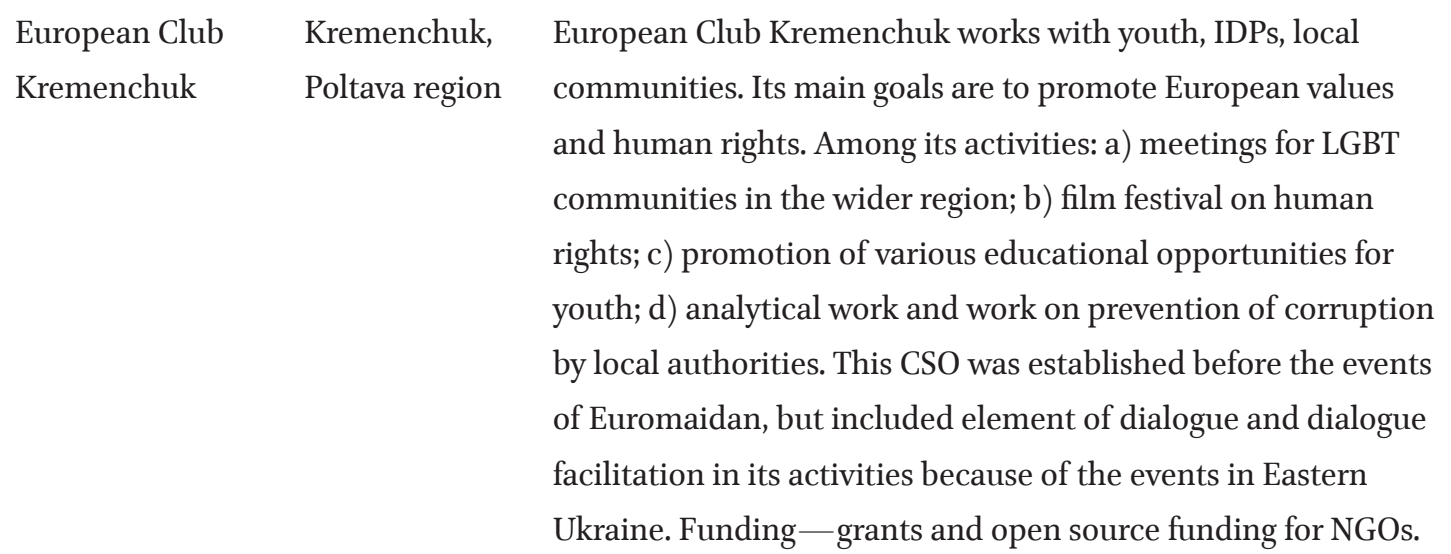


MediatEUr Brussels, Kyiv, MediatEUr works in the area of dialogue support, facilitation, Lviv mediation, peace-tech and dialogue mapping. Its project in Ukraine aimed at creating the Dialogue Support Platform, which connects over 30 Ukrainian dialogue initiatives.

$\begin{array}{ll}\text { Odesa Regional Odesa } & \text { Following the events in Odesa in May 2014, a group of mediators } \\ \text { Group of } & \text { from Odesa created a platform for dialogue and introduced so- } \\ \text { Mediation } & \text { called Odesa Model of Dialogue. They started weekly dialogues in } \\ & \text { Odesa, later - with participation of Kharkiv. Members of Odesa } \\ & \text { Regional Group of Mediation participate as dialogue facilitator in } \\ & \text { various initiatives. }\end{array}$

\begin{tabular}{|c|c|c|}
\hline $\begin{array}{l}\text { Prostir zmin } \\
\text { (Space for } \\
\text { Changes) }\end{array}$ & $\begin{array}{l}\text { Dnipro and } \\
\text { Dnipropetrovsk } \\
\text { region }\end{array}$ & $\begin{array}{l}\text { This CSO is involved in practicing dialogues between communities } \\
\text { and local authorities in the processes of decentralization. CSO } \\
\text { members were involved in creation of first unified communities } \\
\text { in Dnipropetrovsk region, in dialogues for IDPs and receiving } \\
\text { communities. Prostir zmin was established on the basis on } \\
\text { another NGO, which was operating in the region. Funding comes } \\
\text { from various open grants for NGOs. }\end{array}$ \\
\hline $\begin{array}{l}\text { Ukrainian Center } \\
\text { for Nonviolent } \\
\text { Communication } \\
\text { and Reconciliation } \\
\text { "Dignity Space" }\end{array}$ & Kyiv & $\begin{array}{l}\text { Ukrainian Centre for Nonviolent Communication and } \\
\text { Reconciliation "Dignity Space" — is an initiative established by } \\
\text { coordinators of volunteer network "Evacuation +" and Ukrainian } \\
\text { Coordination Center of International Assistance to Victims of the } \\
\text { Euromaidan Events with support of international experts in non- } \\
\text { violent communication. This CSO organises dialogues, workshops } \\
\text { and trainings using methodology of non-violent communication } \\
\text { (NVC). First activities started during the Revolution of Dignity } \\
\text { (initiative of dialogues between protesters and riot police). The } \\
\text { work continued with various groups of people affected by the } \\
\text { conflict in Eastern Ukraine-in Eastern and Western Ukraine. } \\
\text { With the main location in Kyiv, activities are conducted in } \\
\text { Eastern Ukraine and other cities of the country. Several members } \\
\text { and volunteers run "Dignity Space." Funding are open sources } \\
\text { available for NGOs. }\end{array}$ \\
\hline
\end{tabular}

